\title{
SIKAP DALAM KETENTUAN PIDANA KEIMIGRASIAN DAN PENGAWASAN TERHADAP WARGA NEGARA ASING YANG MELAKUKAN AKTIFITAS DI WILAYAH INDONESIA (ATTITUDE IN THE PROVISIONS OF CRIMINAL IMMIGRATION AND SUPERVISION OF FOREIGN NATIONALS CONDUCTING ACTIVITIES IN THE TERRITORY OF INDONESIA)
}

\author{
Muhammad Fathkul $^{(1)}$, Muhammad Ndaru ${ }^{(2)}$, Nindia Pragita $^{(3)}$ \\ 1,2,3 Politeknik Imigrasi Badan Pengembangan Sumber Daya Manusia Hukum dan HAM RI. Indonesia \\ Email : ${ }^{1)}$ muhammadfatkhul06@gmail.com, ${ }^{2)}$ mndaru96@gmail.com ${ }^{3)}$ nindiapragita11@ gmail.com
}

\begin{abstract}
ABSTRAK
Masuk ke Indonesia adalah sesuatu yang harus memperhatikan semua aturan yang berlaku di Indonesia. Masuk ke Indonesia berarti siap untuk mematuhi semua aturan yang berlaku di Indonesia. Karena bukan sembarang aturan yang ditetapkan untuk mengatur semua urusan terkait keimigrasian Indonesia. Aturan imigrasi (lalu lintas masuk dan keluar) suatu negara berdasarkan hukum internasional adalah hak dan kewenangan negara tersebut. Dengan kata lain, ini merupakan indikator kedaulatan suatu negara. Pengawasan keimigrasian adalah rangkaian kegiatan yang dilakukan untuk mengumpulkan, mengolah, dan menyajikan data dan informasi keimigrasian bagi warga negara Indonesia dan luar negeri guna memastikan kepatuhan terhadap ketentuan peraturan perundang-undangan keimigrasian. Selama periode ini pengawasan mencakup seluruh kegiatan yang bertujuan untuk memastikan bahwa tugas kegiatan dilaksanakan sesuai dengan rencana yang telah ditetapkan. Dijelaskan kebijakan dan perintah (aturan) yang diberikan. Imigrasi melibatkan pelaksanaan kedaulatan negara, yang merupakan hak suatu negara untuk mengizinkan atau menolak masuknya orang asing.
\end{abstract}

Kata kunci : Perundang-undangan, Keimigrasian, Hukum.

\begin{abstract}
Entering Indonesia is something that should pay attention to all the rules that apply in Indonesia. Entering Indonesia means being ready to comply with all applicable rules in Indonesia. Because it is not just any rule set to regulate all matters related to Indonesian immigration. The rules of immigration (traffic in and out) of a country under international law are the rights and authorities of that country. In other words, it is an indicator of a country's sovereignty. Immigration supervision is a series of activities carried out to collect, process, and present immigration data and information for Indonesian and foreign citizens to ensure compliance with the provisions of immigration legislation. During this period the supervision includes all activities aimed at ensuring that the task of activities is carried out in accordance with the established plan. Described policies and commands (rules) are given. Immigration involves the exercise of state sovereignty, which is a country's right to allow or deny the entry of foreigners.
\end{abstract}

Key words: Legislation, Immigration, Law. 


\section{PENDAHULUAN \\ Latar Belakang}

Warga negara adalah penduduk suatu negara atau bangsa menurut asal, tempat lahir, dll. Yang mempunyai hak dan kewajibankewarganegaraan secara penuh, tempat tinggal tetap di negara tersebut, yang dapat dibedakan menjadi warga negara antara lain penduduk asli dan warga negara asing (WNA). Orang asing yangmasukdan tinggal di Indonesia sudahdiatur pada undang-undang mengenai masuk dan keluar dari Indonesia, dokumen perjalanan Republik Indonesia, visa, izin masuk dan tinggal, pengawasanimigrasi, tindakan administratif imigrasi dan penyelidikan. Perkembangan dorongan global saat ini meningkatkan mobilitas penduduk dunia.. Warga Negara Indonesia (WNI) adalah mereka yang diakui oleh hukum sebagai warga negara Republik Indonesia. Seseorang yang akan mengeluarkan kartu identitas oleh kabupaten atau provinsi tempat dia terdaftar sebagai penduduk / warga negara. Individu akan diberikan nomor identifikasi unik (Nomor Identifikasi Penduduk, NIC) ketika berusia 17 tahun dan terdaftar di lembaga pemerintah. Paspor yang dikeluarkan oleh suatu negara kepada warganya sebagai dokumen identitas dalam tatanan hukum internasional yang menyebabkan berbagai efek, baik yang menguntungkan atau merugikan kepentingan dan kehidupan bangsa dan negara Indonesia, sehingga peraturan perundang-undangan yang diperlukan yang menjamin kepastian hokum imigrasi yaitu Undang-Undang Nomor 6 tahun 2011 Tentang Keimigrasian.Keindahan alam Indonesia menjadi daya tarik bagi wisatawan asing kunjungan ke Indonesia. Namun, dengan jumlah wisatawan asing datang ke Indonesia, Asing pelanggaran tidak sedikit di Indonesia. Negara berwilayah Indonesia dari Sabang sampai Meraukeadalah negara yang subur, kaya sumber daya alam seperti bahan baku dan rempahrempah, serta memiliki potensi alam berupa tanah dan laut untuk dieksplorasi, sehingga banyak pengunjung internasional untuk mengunjungi atau bekerja di Indonesia Orang asing yang masuk ke Indonesia harus memberikan kontribusi atau manfaat yang positif baik bagi negara maupun masyarakat, seperti peningkatan devisa, transfer ilmu, penelitian kolaboratif, kerjasama pada bidang pendidikan, kesehatan, teknologi, dll serta bukan sebaliknya. Keberadaan dan aktivitas mereka harus memberikan kontribusi untuk kemajuan di segala bidang. Sebagai negara yang berdaulat, Indonesia dalam perkembangan hukum tidak lepas dari hukum yang mengatur tentang orang asing yang masuk ke dalam wilayah Negara Kesatuan Republik Indonesia, serta yang mengatur tentang warga negara Indonesia yang keluar dari negaranya. Untuk itu diperlukan aturan atau undang-undang yang mengatur tentang perdagangan orang yang masuk dan keluar Indonesia, keberadaan dan aktivitas warga negara asing di Indonesia, yaitu undang-undang keimigrasian. Dalam kontek regulas terkait pengawasan kegiatan orang asing, sudah diatur di dalam Undang-Undang Nomor 6 Tahun 2011 tentang Keimigrasian.

\section{Metode Penelitian}

\section{Pendekatan}

Jenis pendekatan yang digunakan adalah penelitian normatif. Ini adalah studi yang mendeskripsikan, menjelaskan, menganalisis, dan kemudian membahas masalah untuk menarik kesimpulan tentang peristiwa tersebut.. Pendekatan penelitian ini juga memanfaatkan studi dokumen, yaitu penggunaan berbagai data sekunder seperti peraturan perundangundangan, putusan pengadilan, teori hukum, dan dapat berupa pendapat ahli. Jenis penelitian normatif ini menggunakan 
analisis kualitatif untuk menjelaskan data yang ada dengan kata-kata atau pernyataan tanpa angka.

Untuk pendekatan normative, dibagi menjadi 7 pendekatan, yaitu sebagai berikut:

\section{Pendekatan Perundang-Undangan}

Pendekatan hukum ini dilakukan dengan cara memeriksa koherensi atau kesesuaian antara Undang-undang Dasar dan Undang-undang, atau antara satu undang-undang dengan undang-undang lainnya, dsb.

Pendekatan Kasus

Pendekatan ini dilakukan dengan menganalisis kasus-kasus yang terkait dengan masalah hukum yang diangkat. Kasus saat ini adalah kasus yang sudah mendapat keputusan akhir. Hal terpenting yang harus diperhatikan dalam setiap putusan tersebut adalah pertimbangan hakim dalam mengambil putusan sehingga dapat dijadikan sebagai bahan argumentasi dalam menyelesaikan permasalahan hukum yang bersangkutan. Pendekatan historis

Pendekatan ini digunakan untuk memahami filosofi hukum dari waktu ke waktu dan untuk memahami perubahan dan perkembangan filosofi yang mendasari norma hukum tersebut. Pendekatan ini dilakukan dengan mengkaji konteks dan mengembangkan kerangka hukum terkait dengan permasalahan hukum terkait.

Pendekatan komparatif

Pendekatan ini dicapai dengan membandingkan peraturan hukum atau putusan pengadilan suatu negara dengan peraturan hukum negara lain (satu negara atau lebih), tetapi harus kurang lebih sama. Perbandingan tersebut dilakukan untuk mengetahui persamaan dan perbedaan antara peraturan hukum/ putusan pengadilan tersebut.

Pendekatan konseptual

Pendekatan ini berbeda dengan keyakinan dan ajaran yang berkembang dalam hukum. Pendekatan ini penting dilakukan karena pemahaman terhadap pendapat/doktrin yang berkembang dalam hukum dapat menjadi dasar untuk menciptakan dalil hukum dalam menyelesaikan permasalahan hukum yang ada. Pendapat/doktrin akan memperjelas gagasan dengan memberikan definisi, konsep, dan asas hukum yang relevan dengan masalah tersebut.

Pendekatan analitis

Pendekatan ini dilakukan melalui analisis dokumen hukum yaitu mengetahui makna istilah yang digunakan dalam perundang-undangan pada tataran konseptual, serta mengetahui penerapannya dalam praktik hukum dan dalam pengambilan keputusan.

Dalam penelitian ini akan menggunakan metode penelitian pendekatan perundang-undangan, dengan bahan sebagai berikut:

\section{Metode pengumpulan data}

Metode pengumpulan data dalam penelitian ini adalah penelitian kepustakaan, yaitu metode pengumpulan data melalui penelitian dan telaah bahan pustaka (literatur, hasil penelitian, jurnal ilmiah, buletin ilmiah, jurnal ilmiah, dll).

\section{Metode analisis data}

Teknik analisis data yang digunakan dalam penelitian ini adalah teknik analisis data normatif dimana hasil penelitian dibahas dan diinterpretasikan berdasarkan pemahaman tentang hukum, peraturan perundang-undangan, teori hukum, dan doktrin hukum yang berkaitan dengan mendengarkan suatu topik tertentu. Di sini norma hukum digunakan sebagai titik tolak, kemudian dikorelasikan dengan fakta-fakta yang relevan (fakta hukum) yang digunakan sebagai titik pangkal sekunder, dan kesimpulan tentang masalah diambil berdasarkan proses silogisme. 


\section{PEMBAHASAN}

Memasuki Wilayah

Indonesia

merupakan suatu hal yang mesti memerhatikan segala aturan yang terkait ataupun berlaku di Indonesia. Memasuki Wilayah Indonesia artinya pula siap mengikuti segala aturan yang berlaku di Indonesia. Sebab tak sembarang aturan yang telah dibuat untuk mengatur segala hal terkait Keimigrasian Indonesia. Pengaturan bidang keimigrasian (lalu lintas keluar masuk) suatu negara, berdasarkan hukum internasional menurut Ramadhan K.H. dan Abrar Yusra merupakan hak dan wewenang suatu negara. Dengan perkataan lain, merupakan salah satu indikator kedaulatan suatu negara.

Pengawasan Keimigrasian adalah serangkaian kegiatan yang dilakukan untuk mengumpulkan, mengolah, serta menyajikan data dan informasi keimigrasian warga negara Indonesia dan orang asing dalam rangka memastikan dipatuhinya ketentuan peraturan perundangundangan di bidang Keimigrasian. Sedangkan pengawasan adalah segenap kegiatan untuk meyakinkan dan menjamin bahwatugas/ pekerjaan telah dilakukan sesuai dengan rencanayang telah ditetapkan. Kebijaksanaan yang telah digariskan dan perintah (aturan) yang diberikan (Siagian,2003:112).

Untuk menjamin agar semua pekerjaan yang telah diberikan oleh pimpinan kepada bawahannya dapat berjalan sesuai menurut rencana, maka seorang pimpinan tersebut harus memiliki kemampuan untuk memandu, menuntut, membimbing, memotivasi, mengemudikan organisasi, menjalin jaringan komunikasi yang baik, sumber pengawasan yang baik, serta membawa pengikutnya kepada sasaran yang hendak dituju sesuai ketentuan, waktu dan perencanaan (Kartono, 2002:81). Karena itu pengawasan harus dipandang sebagai suatu sistem informasi, karena kecepatan dan ketetapan tindakan korektif sebagai hasil proses pengawasan bergantung pada macamnya informasi yang diterima. (Fattah, 2004:102). Menurut (Kansil, 2002:12) pengawasan itu sangat penting sekali untuk menjamin terlaksananya kebijakan pemerintah pengawasan adalah suatu usaha untuk menjamin:

a. Keserasian antara penyelenggaraan tugas pemerintah oleh pemerintah daerah dan pemerintah pusat

b. Kelancara penyelenggaraan pemerintah secara berdaya guna dan berhasil guna

Pengawasan pemerintah pusat terhadap pemerintah daerah meliputi:

a. Pengawasan Umum.

Dimaksudkan agar penyelenggaraan pemerintah daerah dapat berjalan dengan baik. Yang melakukan pengawasan umum ialah mentri dalam negeri, kepala wilayah yaitu gubernur, bupati, walikota, kepala daerah sebagai pemerintah daerah.

b. Pengawasan Prevektif.

Dimana mengharuskan setiap peraturan daerah dan keputusan kepala daerah mengenai pokok tertentu berlalu sesudah mendapat pengawasan.

c. Pengawasan Refresif.

Menyangkut penangguhan atau pembatasan peraturan daerah yang bertentangan dengan kepentingan umum atau perundangan yang tingkatnya lebih tinggi.

Terwujudnya tujuan yang dikehendaki oleh organisasi sebenarnya tidak lain merupakan tujuan dari pengawasan. Sebab setiap kegiatan pada dasarnya selalu mempunyai tujuan tertentu. Oleh karena itu pengawasan mutlak diperlukan dalam usaha pencapaian suatu tujuan. Menurut Situmorang dan Juhir (2001:22) maksud pengawasan adalah untuk : 
1. Mengetahui jalannya pekerjaan apakah lancar atau tidak.

2. Memperbaiki kesalahan-kesalahan yang dibuat oleh pegawai dan mengadakan pencegahan agar tidak terulang kembali kesalahan-kesalahan yang sama atau timbulnya kesalahan yang baru.

3. Mengetahui apakah penggunaan budget yang telah ditetapkan dalam refncana terarah kepada sasarannya dan sesuai dengan yang telah direncanakan.

4. Mengetahui pelaksanaan kerja sesuai dengan program (fase tingkat pelaksanaan) seperti yang telah ditentuka dalam planning atau tidak.

5. Mengetahui hasil pekerjaan dibandingkan dengan yang telah ditetapkan dalam planning.

Yaitu standard Rachman (dalam Situmorang dan Juhir, 2001:22) juga mengemukakan tentang maksud pengawasan, yaitu:

1. Untuk mengetahui apakah segala sesuatu berjalan sesuai dengan rencana yang telah ditetapkan

2. Untuk mengetahui apakah sesuatu telah berjalan sesuai dengan instruksi serta prinsip-prinsip yang telah ditetapkan.

3. Untuk mengetahui apakah kelemahankelemahan serta kesulitan-kesulitan dan kegagalan-kegagalannya, sehingga dapat diadakan perubahan-perubahan untuk memperbaiki serta mencegah pengulangan kegiatan-kegiatan yang salah.

4. Untuk mengetahui apakah segala sesuatu berjalan efisien dan apakah dapat diadakan perbaikan-perbaikan lebih lanjut, sehingga mendapat efisiensi yang lebih benar.

Dari kedua pendapat di atas dapat diatas dapat disimpulkan bahwa maksud pengawasan adlaah untuk mengetahui pelaksanaan kerja, hasil kerja, dan segala sesuatunya apakah sesuai dengan yang direncanakan atau tidak, seta mengukur tingkat kesalahan yang terjadi sehinga mampu diperbaiki ke arah yang lebih baik. Sementara berkaitan dengan tujuan pengawasan, Maman Ukas (2004:337) mengemukakan:

1. Memberi pegawai-pegawai manajemen dengan informasiinformasi yang tepat, teliti an lengkap tentang apa yang akan dilaksanakan.

2. Memberi kesempatan kepada pegawai dalam meramalkan rintangan-rintangan yang akan menggangu produktivitas kerja secara teliti dan mengambil langkah-langkah yang tepat untuk menghapuskan atau mengurangi gangguan - gangguan yang terjadi.

3. Setelah kedua hal di atas telah dilaksanakan, kemudian para pegawai dapat membawa kepada langkah terakhir dlaam mencapai produktivitas kerja yang maksimum dan pencapaian yang memuaskan dari pada hasil-hasil yang diharapkan.

Sementara tujuan pengawasan menurut Soekarno (dalam Safrudin, 2002:36) adalah: untuk mengetahui apakah sesuatu berjalan sesuai dengan rencana yang digariskan, menegtahui apakah sesuatu dilaksanakan sesuai dengan instruksi serta asas yang ditentukan, mengetahui kesulitagnkesulitan dan kelemahan-kelemahan dlam bekerja, mengetahui apakah sesuatu berjalan efisien atau tidak, dan mencari jalan keluar jika ternyata dijumpai kesulitan-kesulitan, kelemahan-kelemahan, atau kegagalan ke arah perbaikan. Berdasarkan pendapat para ahli di atas, dapat diketahui bahwa pada pokoknya tujuan pengawasan adalah: 
1. Membandingkan antara pelaksanaan dengan rencana serta instruksiinstruksi yang telah di buat.

2. Untuk mengetahui ada tidaknya kesulitan-kesulitan, kelemahankelemahan atau kegagalan-kegagalan serta efisiensi dan efektivitas kerja.

Pengawasan ialah suatu proses dimana pimpinan ingin mengetahui apakah hasil pelaksanaan pekerjaan yang dilakukan oleh bawahannya sesuai dengan rencana, perintah, tujuan atau kebijaksanaan yang telah ditentukan. Pengawasan menurut Bagir Manan merupakan pengikat kesatuan, agar bandul kebebasan berotonomi tidak bergerak begitu jauh sehingga mengurangi bahkan mengancam kesatuan, tetapi pengawasan sebagai pengikat tidak juga dapat ditarik begitu kencang, karena akan menyebabkan kebebasan desentralisasi akan berkurang bahkan mungkin terputus. Bagir Manan juga mengemukakan bahwa pengawasan atau control mengandung dimensi pengendalian dan juga pembatasan. Pengawsan dimaksud mengandung pembatasan-pembatasan antara kewenangan-kewenangan pejabat dan juga lembaga /institusi yang berwenang mengawasi.

Imigrasi mencakup pelaksanaan implementasi kedaulatan negara adalah hak suatu negara untuk mengizinkan atau melarang orang asing masuk atau tidak. Seorang orang asing yang memasuki wilayah suatu Negara akan dikenakan hukum negara serta warga negara itu sendiri (J.G. Starke, 200: 2010) Untuk mengatur masalah ini, Indonesia memiliki hukum dan peraturan mengatur mereka, yaitu Undang-Undang Keimigrasian No. 6 tahun 2011. Undang-undang adalah peraturan yang mengatur masalah perdagangan orang masuk atau tinggalkan wilayah Republik Indonesia dan pantau orang asing di wilayah Republik Indonesia. Pasal 9 (1) UU Keimigrasian Edisi 6 tahun 2011 menyatakan: "Siapa saja yang masuk atau keluar dari wilayah Indonesia harus melewati pemeriksaan yang dilakukan oleh petugas imigrasi di pos pemeriksaan imigrasi ". Situasi seperti ini tidak hanya berdampak positif bagi negara, tetapi juga tetapi juga memiliki dampak negatif pada berbagai pelanggaran atau kejahatan langsung atau tidak langsung terkait dengan masalah imigrasi, seperti:

1. Pelanggaran atau kejahatan konvensional, misalnya:

penyalahgunaan izin imigrasi, lembur, pencurian dokumen, pemalsuan dokumen, dokumen penjualan.

2. Kejahatan terhadap pencurian barang milik Negara, misalnya: korupsi, pembalakan liar, penangkapan ikan ilegal.

3. Kejahatan lintas negara, misalnya terorisme, pencucian uang, penyelundupan, perdagangan

perempuan dan anak-anak, perdagangan dan penggunaan narkotika dan zat-zat psikotropika.

4. Kejahatan dengan implikasi kontingen, misalnya: separatisme, manifestasi anarkis, Kejahatan terkait SARA (Bagian Pemantauan dan Penegakan) Imigrasi, 2008: 12).

Dalam Undang-Undang Keimigrasian No. 6 tahun 2011 diundangkan klasifikasi pelanggaran pidana yang dapat dilakukan dalam masalah imigrasi, yang terdiri dari kejahatan dan pelanggaran. Kejahatan didefinisikan sebagai suatu tindakan perilaku menyimpang, bertentangan dengan hukum dan tindakan memalukan pandangan komunitas. Imigrasi diatur dalam Bab XI tentang ketentuan pidana, yaitu dari pasal 113 ke pasal 136. Imigrasi adalah suatu tindakan kejahatan umum, karena pelanggaran keimigrasian tidak memiliki posisi sendiri dalam hukum pidana, sehingga kejahatan 
imigrasi bukanlah kejahatan secara khusus. Tindakan keimigrasian terhadap orang asing dilakukan sesuai dengan Peraturan Pemerintah No. 31 tahun 1994 tentang pengawasan dan aksi orang asing Imigrasi. Penerapan hukum di bidang keimigrasian sangat bergantung pada kebaikan atau apakah pelaksanaan kegiatan pengawasan asing oleh semua pihak. UU No. 6 tahun 2011 tentang imigrasi, khususnya Pasal 69, ayat 1, mengamanatkan bahwa pengawasan terhadap alien dilakukan secara terkoordinasi antara instansi pemerintah terkait dengan orang asing melalui pembentukan tim pengawasan orang asing (tim PORA) di tingkat pusat dan daerah. Tim ini terdiri dari polisi, TNI, layanan sosial tenaga kerja dan organisasi lainnya. Di Indonesia, pengawasan dan penghormatan terhadap orang asing dilakukan wewenang Kementerian Hukum dan Hak Asasi Manusia. Untuk melaksanakan tugas fungsinya, Kementerian Hukum dan Hak Asasi Manusia Indonesia membagi dan / atau mendelegasikan wewenang ke lembaga vertikal. Pengawasan dan eksekusi imigrasi orang asing di tingkat pusat dilakukan oleh Direktorat Jenderal Imigrasi, di tingkat provinsi oleh kantor regional Departemen Kehakiman dan Hak Asasi Manusia Divisi Imigrasi.

Divisi Imigrasi bertanggung jawab untuk membantu Kepala Kantor Wilayah dengan bagian dari tugas Kantor Regional di bidang imigrasi berdasarkan kebijakan teknis yang diadopsi oleh Direktur Jenderal Imigrasi. Dengan menerapkan Untuk melakukan ini, Bagian Imigrasi melakukan fungsi-fungsi berikut:

1. Mempromosikan dan mengendalikan pelaksanaan tugas teknis di bidang lalu lintas status keimigrasian, tempat tinggal dan imigrasi, dan kepatuhan terhadap hukum imigrasi dan imigrasi. pusat penahanan imigrasi;
2. Implementasi kerja sama, pemantauan, evaluasi dan persiapan laporan implementasi tugas teknis di bidang perdagangan imigrasi, izin tinggal dan status imigrasi, serta langkah-langkah imigrasi dan pusat penahanan bagi imigran;

3. Kompilasi rencana, program, kegiatan, dan anggaran dalam Divisi Imigrasi; dan

4. Mengkoordinasikan perencanaan dan implementasi manajemen sumber daya manusia, fasilitas dan infrastruktur, serta administrasi keuangan dalam Unit Pelaksana Teknis Imigrasi berkoordinasi dengan divisi keimigrasian.

Investigasi dilakukan oleh penyelidik imigrasi di Jakarta Divisi Imigrasi Kantor Regional Kementerian Hukum dan Hak Asasi Manusia di Sumatera Barat terhadap orang asing, korban penyalahgunaan dokumen imigrasi telah dianeksasi kurang efektif dan kurang optimal karena masih banyak orang asing yang melakukannya pelanggaran imigrasi. Tidak sedikit orang asing yang mengunjung Indonesia terlibat dalam kegiatan yang tidak mematuhi izin tinggal yang dikeluarkan. Dalam praktek penyelesaian pelanggaran imigrasi di Divisi Imigrasi Kantor Regional Kementerian Hukum dan Hak Asasi Manusia Sumatera Barat terutama dengan tindakan formulir administrasi untuk membebankan biaya dan / atau pengusiran dan sangat jarang proses peradilan pidana (projustisia).

Setiap Orang Asing yang berada di Wilayah Indonesia wajib memiliki Izin Tinggal. Sebelum memasuki ataupun keluar dari wilayah Indonesia, warga negara asing yang hendak memasuki ataupun keluar Wilayah Indonesia wajib memiliki dokumen perjalanan yang 
berlaku dan masih aktif. Hal ini sesuai dengan ketentuan yang berlaku pada Pasal 8 ayat (1) Undang-undang tentang Keimigrasian Tahun 2011. Dokumen perjalanan yang dimaksud dalam hal di atas ialah, Paspor dan atau Surat Perjalanan Laksana Paspor. Paspor disini pun dibedakan menjadi tiga paspor, yakni Paspor Diplomatik, Paspor Dinas, dan Paspor Biasa.

Setelah warga negara asing yang hendak masuk ataupun keluar Wilayah Indonesia memiliki dokumen perjalanan, maka tahap selanjutnya warga negara asing tersebut wajib memiliki Visa. Namun terdapat beberapa pengecualian terhadap warga negara asing asal negara-negara yang telah ditetapkan oleh pihak Indonesia sebagai negara bebas visa kunjungan. Warga negara asing asal negara bebas visa kunjungan.tidak perlu memiliki visa untuk dapat berkunjung ke Indonesia, sebab mereka telah dianggap memiliki visa kunjungan yang berlaku selama 30 hari kedepan saat setelah masuknya warga negara asing tersebut ke Wilayah Indonesia.

\section{Penegakan \\ Hukum terhadap \\ Penyalahgunaan Izin Tinggal Pengertian Penegakan Hukum}

Secara umum Penegakan hukum dapat diartikan sebagai tindakan menerapkan dan memastikan tegaknya hukum itu, apabila di perlukan. Aparatur penegak hukum itu diperkenankan untuk menggunakan daya paksa' Sedangkan menurut Satjipto Rahardjo, "Penegakan Hukum adalah suatu proses untuk mewujudkan keinginan-keinginan hukum yaitu pikiran-pikiran badan pembuat undangundang yang dirumuskan dalam peraturan-peraturan hukum menjadi kenyataan. Mengingat demikian banyaknya instansi (struktur kelembagaan) dan pejabat (kewenangan) yang terkait di bidang penegakan hukum, maka reformasi penegakan hukum tampaknya memerlukan peninjauan dan penataan kembali seluruh struktur kekuasaan/kewenangan penegakan hukum. Jadi, "reformasi penegakan hukum" mengandung di dalamnya "reformasi kekuasaan/kewenangan di bidang penegakan hukum. Soerjono soekanto perangkat sarana hukum tertentu untuk memaksakan sanksi hukum guna menjamin pentaatan terhadap ketentuan yang ditetapkan tersebut. Penegakan hukum juga dapat diartikan sebagai proses dilakukannya upaya untuk tegaknya atau berfungsinya norma-norma hukum secara nyata sebagai pedoman perilaku dalam hubungan- hubungan hukum terhadap kehidupan bermasyarakat dan bernegara. Ditinjau dari sudut subyeknya, penegakan hukum itu dapat dilakukan oleh subyek yang luas dan dapat pula diartikan sebagai upaya Penegakan Hukum itu melibatkan semua subyek hukum dalam setiap hubungan hukum. Siapa saja yang menjalankan aturan normatif atau melakukan sesuatu atau tidak melakukan sesuatu dengan mendasarkan dari pada norma aturan hukum yang berlaku, berarti dia menjalankan atau menegakkan aturan hukum. Dalam arti sempit, dari segi subyeknya itu,penegakan hukum itu hanya diartikan sebagai upaya aparatur penegakan hukum tertentu untuk menjamin .

Menjelaskan tentang Penegakan hukum bahwa : "Penegakan hukum adalah kegiatan menyerasikan hubungan nilai-nilai yang terjabarkan didalamkaidahkaidah/ pandangan nilai yang mantap dan mengejewantah dan sikap tindak sebagai rangkaian penjabaran nilai tahap akhir untuk menciptakan, memelihara dan mempertahankan kedamaian dalam hidup."

Berdasarkan teori Efektivitas Hukum yang dikemukan oleh Soerjono Soekanto, ada 5 hal yang mempengaruhi Efektif atau tidaknya Penegakan Hukum yaitu : a. Faktor hukumnya sendiri. 
b. Faktor sarana dan fasilitas pendukung

c. Faktor masyarakat.

d. Faktor kebudayaan.

Menurut Lawrence Meir Friedman, seorang ahli sosiologi hukum dari Stanford University, Ia berpendapat bahwa berhasil atau tidaknya Penegakan Hukum bergantung pada tiga unsur sistem hukum yang diantaranya adalah :

a. Keputusan yang baru di susun dan baru di buat yang mana di sini di tekankan pada suatu hukum akan dibuat jika melalui peristiwa terlebih dahulu.

b. Struktur Hukum (legal structure) dan Struktur Hukum/Pranata Hukum. Struktur hukum (legal structure) yaitu kerangka bentuk yang permanen dari sistem hukum yang menjaga proses tetap berada di dalam batasbatasnya. Sedangkan struktur Hukum/pranata hukum disebut sebagai sistem struktural yang menentukan bisa atau tidaknya hukum itu dilaksanakan dengan baik. Karena Hukum tidak dapat berjalan atau tegak bila tidak ada aparat penegak hukum yang kredibilitas, kompoten dan independen.

c. Budaya Hukum (legal culture), dimaknai sebagai suasana pikiran sosial dan kekuatan sosial yang menentukan bagaimana hukum digunakan, dihindari, atau disalahgunakan. Maka secara singkat dapat dikatakan bahwa yang disebut budaya hukum adalah keseluruhan sikap dari warga masyarakat dan sistem nilai yang ada dalam masyarakat yang akan menentukan bagaimana seharusnya hukum itu berlaku dalam masyarakat yang bersangkutan.

\section{Proses Tindakan Hukum Pidana}

Tindakan Hukum Pidana berupa penyidikan Keimigrasian yang merupakan bagian dari pada rangkaian Integrated
Criminal Justice atau sistem Peradilan pidana (penyidikan, penuntutan, peradilan). Menurut pasal 1 ayat 8 Undang-undang Nomor 6 tahun 2011 tentang keimigrasian menyebutkan bahwa : "Penyidik Pegawai Negeri Sipil yang selanjutnya disebut dengan PPNS Keimmigrasian adalah pejabat Imigrasi yang diberi wewenang oleh undang undang untuk melakukan penyidikan tindak pidana keimigrasian" Orang asing yang melalukan penyalahgunaan visa kunjungan dapat di pidana sebagai mana yang disebutkan pada pasal 122 undang- undang No.6 tahun 2011 tentang keimigrasian bahwa : "Dipidana dengan pidana penjara paling lama 5 (lima) tahun dan pidana denda paling banyak Rp. 500.000.000,00 (lima ratus juta rupiah) :

1. Setiap orang asing yang dengan sengaja menyalahgunakan atau melakukan kegiatan yang tidak sesuai dengan makud dan tujuan pemberian izin tinggal yang diberikan kepadanya;

2. Setiap orang yang menyuruh atau memberikan kesempatan kepada orang asing menyalahgunkan atau melakukan kegiatan yang tidak sesuai dengan maksud atau tujuan pemberian Izin Tinggal yang diberikan kepadanya".

\section{Karantina Imigrasi}

Karantina Imigrasi adalah tempat penampungan sementara bagi orang asing yang dikenakan proses pengusiran atau deportasi atau tindakan keimigrasian lainnya. Namun Karantina Imigrasi diganti dengan Rumah Detensi Imigrasi berdasarkan Peraturan Pemerintah Nomor 31 Tahun 2013 tentang Rumah Detensi Imigrasi. Pasal 1 ayat (33) Rumah Detensi Imigrasi yang selanjutnya disingkat Rudenim adalah unit pelaksana teknis yang menjalankan fungsi Keimigrasian sebagai tempat penampungan sementara bagi orang 
asing yang dikenai Tindakan Administratif dan menunggu proses pemulangan ke negaranya. Pasal 1 ayat (34) Ruang Detensi Imigrasi adalah tempat penampungan sementara bagi orang asing yang dikenai Tindakan Administratif Keimigrasian yang berada di Direktorat Jenderal Imigrasi dan Kantor Imigrasi Pasal 2 menyatakan bahwa penempatan orang asing di Rudenim atau Ruang Detensi Imigrasi, dalam hal yang bersangkutan :Berada di wilayah Negara Republik Indonesia tanpa izin keimigrasian yang sah

1. Menunggu proses pengusiran atau deportasi

2. Menunggu proses keputusan Menteri Hukum dan Hak asasi Manusia mengenai permohonan keberatan yang diajukan

3. Terkena tindakan Keimigrasian dan

4. Telahselesaimenjalani hukuman dan belum dapat dipulangkan atau pengusiran/deportasi.

\section{Alur Pendeportasian}

Deportasi adalah tindakan paksa mengeluarkan Orang asing dari Wilayah Indonesia.25 Secara tehnis, Proses Pendeportasian terdiri atas beberapa bagian yaitu sebagai berikut :

1) Kepala Kantor Imigrasi mengeluarkan Surat Perintah Administratif (Deportasi)

2) Kepala kantor menerbitkan Surat Perintah pengawalan untuk pemulangan Deteni yang dilakukan oleh Petugas yang ditunjuk.

3) Petugas Imigrasi yang ditunjuk mengkoordinasi kepada pihak Imigrasi di bandara, lalu orang asing tersebut diserahkan kepada Petugas bandara keberangkatan Internasional atau biasa disebut Tempat pemeriksaan Imigrasi (TPI).

\section{Pengawasan Orang Asing}

Pengawasan Orang Asing diatur dalam Peraturan Pemerintah Nomor 31 tahun 2013 tentang peraturan pelaksanaan undang-undang Nomor 6 tahun 2011 tentang Keimigrasian. Adapun tata cara pengawasan terdiri atas :

1) Pengawasan orang asing sebelum memasuki wilayah Indonesia berhubungan dengan konsulat atau keduataan Republik Indonesia khusus atase Imigrasi untuk melayani dan meneliti secara selektif setiap permohonan visa ke Indonesia, serta memutuskan apakah dapat diberikan visa atau tidak. Pengawasan tersebut dilakukan oleh para Atase Imigrasi pada setiap perwakilan di Indonesia di luar negeri pada saat orang asing bersangkutan melakukan permohonan untuk mendapatkan visa.

2) Pengawasan orang asing yang melakukan kegiatan di wilayah Indonesia, pengawasan yang dimaksudkan disini merupakan pengawasan lanjutan, dari setelah orang asing mendapatkan visa sebagai izin masuk di Indonesia baik yang melalui darat, maupun laut melalui tempat pemeriksaan Imigrasi (TPI), Dilakukan pemeriksaan dokumen berupa paspor, visa maupun dokumen keimigrasian lainnya disesuaikan dengan izin keimigrasian yang dimiliki secara sah dan dengan tujuan dan kegiatan yang nantinya dilakukan di Indonesia.

\section{Pengawasan secara adminisratif dilakukan dengan cara :}

a) Pengumpulan, pengolahan serta penyajian data dan informasi mengenai :

b) Pelayanan Keimigrasian bagi orang asing

c) Lalu lintas Orang asing yang masuk atau keluar wilayah Indonesia 


\section{Pengawasan lapangan terhadap orang asing dilakukan dengan cara:}

Pengawasan terhadap keberadaan dan kegiatan Orang asing di wilayah Indonesia, meliputi pengecekan :

a) Keberadaan orang asing;

b) Kegiatan orang asing; dan

c) Kelengkapan Dokumen Perjalanan atau Izin tinggal yang dimiliki.

\section{Penyelesaian KasusPenyalahgunaan Visa Kunjungan}

Penyelesaian kasus tersebut pihak imigrasi mengikuti Undang -Undang Nomor 6 Tahun 2011 tentang Keimigrasian. Dalam kaitannya dengan penanggulangan terhadap orang asing yang menyalahgunakan Izin Keimigrasian dilakukan sesudah terjadinya atau terbukti adanya penyalahgunaan Izin Keimigrasian. Tindakan ini bersifat yuridis dan bisa juga bersifat administrasi.

Tindakan Yuridis

Dalam tindakan yuridis penyalahgunaan bisa mengikuti aturan Undang - Undang Nomor 6 Tahun 2011 tentang Keimigrasian dalam Pasal 122 butir a :

"setiap Orang Asing yang dengan sengaja menyalahgunakan atau melakukan kegiatan yang tidak sesuai dengan maksud dan tujuan pemberian Izin Tinggal yang diberikan kepadanya dipidana dengan pidana penjara paling lama 5 (lima) tahun dan pidana denda paling paling banyak Rp500.000.000,00 (lima ratus jutarupiah)"

Jadi tindakan yuridis adalah orang asing yang dengan sengaja menyalahgunakan maksud pemberian izin keimigrasian dan harus dibuktikan di pengadilan oleh hakim dan kemudian dapat dikenakan sanksi pidana sesuai dengan ketentuan peraturan Perundang undangan yang berlaku.

a. Tindakan Administratif

Menurut Pasal 75 Undang - Undang Nomor 06 Tahun 2011 yang mengatur mengenai tindakan keimigrasian terhadap orang asing diwilayah Indonesia, yaitu:

1. Pejabat Imigrasi berwenang melakukan Tindakan Administratif Keimigrasian terhadap Orang Asing yang berada di Wilayah Indonesia yang melakukan kegiatan berbahaya dan patut diduga membahayakan keamanan dan ketertiban umum atau tidak menghormati atau tidak menaati peraturan Perundang - undangan.

2. Tindakan Administratif Keimigrasian sebagaimana dimaksud pada ayat (1) dapat berupa:

a. Pencantuman dalam daftar Pencegahan atau Penangkalan;

b. Pembatasan, perubahan, atau pembatalan Izin Tinggal;

c. larangan untuk berada di satu atau beberapa tempat tertentu di Wilayah Indonesia;

d. Keharusan untuk bertempat tinggal di suatu tempat tertentu di Wilayah Indonesia;

e. Pengenaan biaya beban; dan/atau

f. deportasi dari Wilayah Indonesia.

Tindakan Administratif Keimigrasian berupa Deportasi dapat juga dilakukan terhadap Orang Asing yang berada di Wilayah Indonesia karena berusaha menghindarkan diri dari ancaman dan pelaksanaan hukuman di negara asalnya.

Penyelesaian kasus penyalahgunaan visa kunjungan di Indonesia pihak Imigrasi melakukan tindakan Admistratif berupa Deportasi warga negara asing yang melakukan tindak pidana penyalahgunaan visa kunjungan, warga negara asing yang sudah di Deportasi tidak boleh kembali ke Indonesia dan pihak imigrasi menangkal warga negara asing masuk ke wilayah indonesia. Karena dengan alasan bahwa orang asing yang bersangkutan tidak mengindahkan peraturan yang mengatur keberadaan orang asing diwilayah Republik Indonesia. 


\section{PENUTUP}

Dari penulisan ini maka dapat disimpulkan bahwa dalam hal penegakan hukum Keimigrasian diatur secara tegas mengenai pelanggaran yang dikenai Tindak Pidana Keimigrasian (projustitia) sehingga faktor yang mempengarui diambilnya Tindakan Pidana Keimigrasian sesuai dengan Pasal 75 ayat (1) UndangUndang Nomor 6 Tahun 2011 tentang Keimigrasian menyebutkan "Pejabat Imigrasi berwenang melakukan Tindakan Pidana Keimigrasian terhadap Orang Asing yang berada di Wilayah Indonesia yang melakukan kegiatan berbahaya dan patut diduga membahayakan keamanan dan ketertiban umum atau tidak menghormati atau tidak menaati peraturan perundang- undangan". Sebagai upaya guna menekan angka pelanggaran oleh warga negara asing, Tindakan Pidana Keimigrasian merupakan tindakan yang kurang efektif mengingat angka pemberian Tindakan Pidana Keimigrasian yang dilakukan oleh Unit Pelaksanaan Teknis Keimigrasian.

\section{DAFTAR PUSTAKA}

Artikel dalam Jurnal Hukum Internasional Lembaga Kajian Hukum Internasional FHUI, Volume i1No.1 Oktober 2003, hal 61.

Indonesia,Undang-undang tentang Keimigrasian, UU No. 6 tahun 2011, LN Tahun 2011 Nomor i52, Pasal 48 angka 8

Indonesia,Undang-undang tentang Keimigrasian, UU No. 6 tahun 2011

Indonesia,Undang-undang tentang Keimigrasian, UU No.6 tahun 2011, LN Tahun 2011 Nomor 52, Pasal 75 angka 6
Syahrin, M.Alvi. (2018). Menakar Kedaulatan Negara dalam Perspektif Keimigrasian. Jurnal Penelitian Hukum De Jure, 18 (1), i43-57.

Syahrin, Malv (2018) Penerapan Wewenang Penyidik Pegawai Negeri Sipil dalam Melakukan Penyidikan Tindak Pidana Keimigrasian. Seminar Hukum Nasional, 4 (1),

Syahrin, Malvi (2018).Penerapan Wewenang Penyidik Pegawai Negeri Sipil dalam Melakukan Penyidikan Tindak Pidana Keimigrasian. Seminar Hukum Nasional, 4(1),

Soerjono Soekanto,'Faktor-faktor yang Mempengaruhi Penegakan Hukum", PTRaja Grafindo Persada, Ed.1-11Jakarta:, 